Religare, ISSN: 19826605, v.16, n.1, agosto de 2019, p.35-56.

\title{
O ensino de História e o fundamentalismo no Islã
}

The teaching of History and fundamentalismo in Islam

\author{
Cristine Fortes Lia ${ }^{1}$ \\ Jéssica Pereira da Costa ${ }^{2}$
}

\section{Resumo}

Este estudo aborda a origem do conceito de fundamentalismo religioso, com foco especial ao muçulmano. O termo surge no início do século XX, nos Estados Unidos, para designar grupos de protestantes americanos que passaram a se nomear de "fundamentalistas", por seguirem os fundamentos e princípios da religião e, assim, diferenciavam-se de outros protestantes que, na visão dos primeiros, estariam desvirtuando a "verdadeira" fé ou prática religiosa. Desta forma, analisa-se como o termo, com origem cristã, passou a ser relacionado com a religião muçulmana. Reflete-se, também, sobre o assunto no ensino de História, visto que a construção a respeito do tema "fundamentalismo" e intolerância religiosa permeia as relações estabelecidas em sala de aula. Para tanto, utiliza-se como fonte de análise a coleção de livros didáticos História, Sociedade $\mathcal{E}$ Cidadania, escrita por Alfredo Boulos Júnior, disponibilizada pelo Ministério da Educação (MEC), por meio do Programa Nacional de Distribuição de Livros Didáticos (PNLD), que tem por objetivo "subsidiar o trabalho pedagógico dos professores" através da distribuição gratuita de livros aos estudantes do Ensino Básico. Observa-se a forma como o conceito "fundamentalismo" aparece nos livros e quais as relações que existem entre o Islã, os muçulmanos e o conceito em questão.

Palavras-chave: Islã; Muçulmanos; Fundamentalismo; Ensino de História.

\section{Abstract}

This study addresses the origin of the concept of religious fundamentalism, with a special focus on the Muslim. The term arises in the early twentieth century in the United States to designate groups of American Protestants who came to be known as "fundamentalists," for following the foundations and principles of religion and thus distinguished themselves from other Protestants who, in their view, would be distorting the "true" faith or religious practice. Thus, it is analyzed how the term, with Christian origin, happened to be related with the Muslim religion. It is also reflected, on the subject in the teaching of

\footnotetext{
1 Doutora em História (PUCRS). Professora do Curso de História, do Programa de PósGraduação em História e do Programa de Pós-Graduação em Letras da Universidade de Caxias do Sul - UCS. Pesquisadora do Instituto Religare (UCS).

${ }^{2}$ Mestre em História (UCS). Professora da Educação Básica do Estado do Rio Grande do Sul.
} 
Religare, ISSN: 19826605, v.16, n.1, agosto de 2019, p.35-56.

History, since the construction on the theme "fundamentalism" and religious intolerance pervades the relationships established in the classroom. For that, the collection of textbooks History, Society \& Citizenship, written by Alfredo Boulos Júnior is used as source, made available by the Ministry of Education (MEC), through the National Textbook Distribution Program (PNLD), which aims to "subsidize the pedagogical work of teachers" through the free distribution of books to students of the Basic Education. It is observed how the concept of "fundamentalism" appears in the books and what relations exist between Islam, Muslims and the concept in question.

Keywords: Islam; Muslims; Fundamentalism; History teaching; Religion

\section{Considerações iniciais: percepções acerca do fundamentalismo muçulmano}

Ao lançar o conceito "fundamentalismo" na barra de pesquisas do Google, das oito primeiras imagens que aparecem, três representam de alguma maneira o Islã. Ao substituir o termo de busca para "grupo fundamentalista", das oito primeiras imagens que enchem a tela, 6 delas apresentam grupos muçulmanos. Ao inserir o mesmo termo de pesquisa no campo "notícias", das 10 manchetes que aparecem na primeira página, as 10 são manchetes que fazem referência a ataques terroristas praticados por grupos fundamentalistas muçulmanos ${ }^{3}$.

Essas 10 manchetes são dos dias 18 a 21 de outubro de 2017 e, sob um olhar superficial, podem parecer um caso isolado. Alguns podem até afirmar que isso se deve ao fato único e exclusivo de que, por conta dos recentes ataques na Somália, estas seriam as notícias mais recentes, portanto, este seria o motivo de aparecerem, contudo, este não é um evento isolado.

Nos últimos anos, tanto a mídia jornalística, quanto a de entretenimento tem nos apresentado a inúmeros casos de ataques, atentados ou atos violentos de desmando e crueldade de grupos fundamentalistas muçulmanos que aderiram ao terrorismo, sendo assim, é possível afirmar que, na atualidade, o

${ }^{3}$ Disponível em: https://www.google.com.br/search?q=grupo+fundamentalista Acesso realizado em outubro de 2017. 
Religare, ISSN: 19826605, v.16, n.1, agosto de 2019, p.35-56.

termo "fundamentalismo" tende a ser rapidamente relacionado ao Islã e seus praticantes, homogeneizando-os.

O termo surgiu no início do século $X X$, para designar grupos de protestantes americanos que passaram a se autointitular de "fundamentalistas", por seguirem os fundamentos e princípios da religião e assim diferenciavam-se de outros protestantes. (ARMSTRONG, 2009)

Os primeiros a utilizá-lo foram os protestantes americanos que, no início do século $\mathrm{XX}$, passaram a denominar-se "fundamentalistas" para distinguir-se de protestantes mais "liberais", que, a seu ver, distorciam inteiramente a fé cristã. Eles queriam voltar às raízes e ressaltar o "fundamental" da tradição cristã, que identificavam como a interpretação literal das escrituras e a aceitação de certas doutrinas básicas. Desde então aplica-se "fundamentalismo" a movimentos reformadores de outras religiões. (ARMSTRONG, 2009, p. 10)

O termo, portanto, nasce na tradição cristã e descreve um movimento reformador moderno que valoriza a doutrina acima de tudo, mas este termo passou a ser empregado para descrever movimentos reformadores dentro de outras vertentes religiosas e, com isso, adquiriu novos sentidos e significados. De acordo com Armstrong (2009), ao ser empregado no Islã, este termo possui o sentido do estudo das normas e princípios da lei islâmica.

Quando existe a referência a fundamentalistas muçulmanos nas mídias, muitas vezes, ela é feita de forma equivocada ao tratar fundamentalismo como sinônimo de violência, intolerância ou atraso. Desta forma, quando empregado para descrever movimentos reformadores modernos dentro do Islã, o termo fundamentalismo adquire algumas particularidades que não estão presentes nos movimentos cristãos.

Existem, inclusive, autores como Demant (2014), que veem o uso da expressão "fundamentalismo muçulmano" como uma atribuição de sentido imprópria, preferindo usar termos como islã político, radicalismo islâmico ou islamismo. Contudo, o próprio pesquisador reconhece que a denominação 
Religare, ISSN: 19826605, v.16, n.1, agosto de 2019, p.35-56.

"fundamentalismo muçulmano" foi consagrada pela mídia, especialmente pelos jornais, por isso torna-se difícil se desprender dela ${ }^{4}$.

Demant (2009) destaca que a origem e a evolução do fundamentalismo muçulmano residem na tentativa de resistir à dominação europeia durante o imperialismo do século XIX e XX. Uma forma de agarrarem-se às suas tradições e impedir a ocidentalização de suas culturas. Embora o Oriente e o Ocidente tenham sido contra pontos culturais e tenham travado disputas militares e econômicas desde a Idade Média (SAID, 2007), foi no século XIX que a cultura ocidental se fez mais presente e de forma mais dominante no Oriente muçulmano.

Cada sociedade atingida pela expansão colonial refletiu sobre as causas da superioridade do Ocidente e o fracasso da própria civilização. Pensadores tanto os que integravam as tradições culturais nativas, quanto os formados pelas novas escolas abertas pelos ocidentais na colônia, precisavam desenvolver respostas e estratégias. Esse processo era sempre penoso, pois se dava num contexto de derrota. Era inevitável se chegar a uma de duas conclusões: ora a própria civilização não estava à altura do desafio, os as forças autóctones não usaram corretamente os recursos da própria tradição. (DEMANT, 2014, p. 199)

O fundamentalismo muçulmano teve seu princípio como movimento de resistência ao domínio colonial do século XIX, além disso, é preciso destacar que ele também é fruto da chamada "crise secular no mundo árabe" (DEMANT, 2014). Esta nasceu como uma forma de tentar realizar e sustentar o fim da dominação imperialista nos séculos XIX e XX, mas enfrentou sua derrocada nos anos 1950 e 1960, devido a sucessivas derrotas de conflitos e guerras civis, como os embates contra Israel, a Guerra do Líbano, a guerra Irã-Iraque, entre outros conflitos. Neste contexto, isto é, diante da ruína do secularismo árabe e da

4Tendo em vista a popularidade da expressão, neste artigo optou-se por utilizar a expressão "Fundamentalismo muçulmano" para se referir aos processos históricos, culturais e religiosos identificados como islamismo ou islã político. 
Religare, ISSN: 19826605, v.16, n.1, agosto de 2019, p.35-56.

crescente interferência Ocidental, o islamismo ou fundamentalismo muçulmano se configurou como uma alternativa atraente à população muçulmana dominada.

A ideologia fundamentalista teve inserção nas várias correntes do Islã como o sunismo e o xiismo. De modo geral, o fundamentalismo muçulmano caracterizou-se por ser contra o modernismo, contra a secularização e contra a ocidentalização. Seus princípios estão em garantir que o fiel se torne um "muçulmano religioso observante, [...] transformar a sociedade formalmente muçulmana em uma comunidade religiosa voltada ao serviço a Deus e estabelecer o reino de Deus em toda a Terra" (DEMANT, 2014, p. 201).

A ideologia fundamentalista fixou-se a partir dos anos 1950 com os primeiros teóricos. Posteriormente, destacam-se três ondas (DEMANT, 2009) de perpetuação desta ideologia para além do mundo árabe-muçulmano.

Ele entrou na cena internacional nos anos 1970 e 1980, que podem ser consideradas o seu período de maturação. Uma segunda onda nos anos 1980 o levou a um auge aparente com a Revolução Iraniana, o assassinato de Sadat no Egito e o Hezbollah no Líbano. Suas atividades se limitavam ainda à própria região médio-oriental - e em geral, ao mundo xiita. (DEMANT, 2014, p. 201)

A terceira fase de expansão do islamismo ou fundamentalismo muçulmano ocorreu no final do século XX com a Guerra do Golfo, o fundamentalismo globalizou-se, ou seja, ganhou dimensões globais com a formação de grupos como o Hamas, o Talebã e a Al-Qaeda. É importante destacar que existem muitas diferenças entre os grupos que possuem uma ideologia fundamentalista dentro do Islã. Diferem quanto a sua forma de inserção nas sociedades da qual fazem parte, na sua atuação política e religiosa e nas concepções ritualísticas e de culto, sendo assim, a ação terrorista ou violenta não é algo inerente ao fundamentalismo religioso. (DEMANT, 2014)

Por exemplo, a Irmandade Muçulmana, grupo fundamentalista que 
Religare, ISSN: 19826605, v.16, n.1, agosto de 2019, p.35-56.

surgiu no Egito, no início do século XX, adotou uma estratégia não radical, mas sim reformista, preferindo um trabalho educacional e político graduais. Já outros grupos defendem que a sociedade foi tão infectada e poluída que só uma revolução radical seria capaz de purificá-la e colocá-la de volta no caminho de Deus, é o caso do Talebã, no Afeganistão.

Para atingir estes objetivos, os grupos radicais defendem a militância violenta, a neo-jahiliyya, pois estão combatendo inimigos externos como os "poluidores" ocidentais e inimigos internos, nos próprios grupos de muçulmanos, que se desviam daquela que é pregada como verdadeira fé. Entre estes grupos, pode-se citar como exemplo o autointitulado Estado Islâmico, conhecido pela sigla ISIS, com origens no norte da África e presença marcante nos atuais conflitos da Síria.

Enquanto religião, o Islã não é homogêneo, devido ao seu caráter de universalização da fé e da forma como o Império árabe e, mais tarde, os impérios muçulmanos se expandiram. Ele adquiriu particularidades locais e regionais nas diferentes regiões que atingiu, sem mencionar nas divisões internas provocadas por disputas políticas ou entre as escolas de pensamento (DEMANT, 2014). Mesmo após o fim da Idade Média, o Ocidente continuou olhando para o Islã com preconceito e estranhamento, descrevendo as populações do Oriente Médio como exóticas, místicas e/ou atrasadas, reafirmando o Ocidente enquanto civilização superior. (SAID, 2007).

Nos últimos anos, os discursos sobre o Islã se multiplicaram nas mídias, muito em função das ações de grupos violentos e/ou terroristas com doutrinas fundamentalistas, como a Al'Qaeda, o ISIS, o Boko Haram ou os conflitos no Oriente Médio com motivações geopolíticas e econômicas, mas que usam como pano de fundo motivações religiosas (DEMANT, 2014). Souza (2016) destaca que as comunidades muçulmanas sofrem com uma islamofobia que, embora não tenha nascido na era contemporânea, ganhou força com a ação dos grupos citados e da atenção midiática. 
Religare, ISSN: 19826605, v.16, n.1, agosto de 2019, p.35-56.

Os discursos sobre os muçulmanos proliferam nos meios de comunicação de massa ocidentais na contemporaneidade [...] Todavia, algumas das discussões fora do âmbito acadêmico tangenciam a questão da fé das pessoas, sejam agressores ou agredidos, caracterizando os muçulmanos enquanto dignos de violência, seja ela física ou simbólica. Essa caracterização oferece uma visão enviesada sobre a comunidade muçulmana e que varia da manutenção da ignorância ao estimulo à violência [...] (SOUZA, 2016. p. 153)

Desta forma, o fundamentalismo muçulmano acabou por ser massificado entre os discursos e representações midiáticas, influenciando na percepção que a sociedade constrói acerca das comunidades muçulmanas, provocando ondas de intolerância e preconceito e gerando reações extremadas, como manifestações contra muçulmanos na Europa ${ }^{5}$ ou atos governamentais, como os norte-americanos que impediram a entrada no país de pessoas vindas de certos países com maioria muçulmana ${ }^{6}$.

Após o 11 de setembro de 2001, as ideias sobre práticas fundamentalistas retornaram aos meios de comunicação com muita expressão. Foram divulgadas inúmeras estratégias para a compreensão e a prevenção contra o fundamentalismo, sempre identificado como uma expressão de fé do Islã e como uma experiência do outro. $O$ século XXI se iniciou na perspectiva da luta do bem contra o mal.

As pessoas que planejaram os ataque suicidas de Nova Iorque e Washington certamente estavam convencidas de que faziam

\footnotetext{
${ }^{5}$ Um exemplo de manifestações contra imigrantes muçulmanos ocorridas na Europa e que levaram milhares às ruas foi notícia no Brasil. Disponível em: http://g1.globo.com/mundo/noticia/2016/02/protestos-contra-imigrantes-levam-milhares-ruasda-europa.html Acesso em: ago 2018.

${ }^{6}$ Em janeiro de 2017, o presidente norte-americano proibiu a entrada de pessoas naturais de sete países de maioria muçulmana e de refugiados de todo o mundo, o decreto foi reconhecido pela suprema corte do país em junho de 2017. Disponível em: https://brasil.elpais.com/brasil/2017/01/27/internacional/1485551816 434347.html Acesso em: ago 2018.
} 
Religare, ISSN: 19826605, v.16, n.1, agosto de 2019, p.35-56.

isto em nome da luta do bem contra o mal. [...] Seus argumentos não precisam ter sido religiosos. Os argumentos do presidente Bush ao jurar vingança foram semelhantes: "Vamos eliminar o mal deste mundo". Bush não fez suas colocações forçosamente a partir de convicções religiosas. Nossos fundamentais não são necessariamente religiosos. Não são apenas fanáticos religiosos que precisam de argumentos para justificar seus atos, que a maioria chama de loucura. Muitas vezes (na maioria das vezes?), quando procuramos argumentos para definir nossos fundamentos, procuramos por inimigos. Os proprietários e os acionistas da indústria de armamentos precisam de argumentos para dizer que são fundamentais. Então o bom passa a ser mau, e o mau passa a ser bom. (DREHER, 2006, p. 06-07)

Assim, no século XXI o mal acabou sendo identificado com o fundamentalismo e, este, sendo visto como uma espécie de criação do Islã. Basicamente, nenhum ocidental se considera fundamentalista. "Você é fundamentalista? Se a pergunta fosse dirigida a nós, certamente responderíamos com um sonoro não" (DREHER, 2006, p. 05). A sociedade é estimulada por diferentes perspectivas em combater essa experiência do outro. Segundo Tzventan Todorov (2010), a comunicação hoje é incomparavelmente mais rápida do que no passado. São informações instantâneas, transmitidas por múltiplos canais e mídias, que promovem uma série de imagens, capazes de atingir o mundo inteiro. Desta forma, é possível determinar e divulgar rapidamente "o rosto das forças hostis" (TODOROV, 2010, p.11).

Esse tipo de informação permite que uma ideia bastante consolidada relacione o mundo muçulmano com toda a forma de fundamentalismo e terrorismo. Todorov (2010) destaca que o medo de se tornar bárbaro conduz a uma espécie de barbarização. $O$ que faz com que os que combatem o fundamentalismo sejam extremamente fundamentalistas. Nesse sentido, é necessário que se promova um entendimento mais complexo sobre os conceitos de fundamentalismo e mundo muçulmano.

A educação precisa estabelecer estratégias de produção de conhecimento sobre o tema que permitam ao estudante romper com as informações pouco 
Religare, ISSN: 19826605, v.16, n.1, agosto de 2019, p.35-56.

aprofundadas que recebe diariamente. É necessário analisar permanentemente o material didático disponibilizado nas escolas brasileiras, para garantir que o mesmo seja transformador no entendimento da realidade e não mantenha os mesmos equívocos das divulgações dos "rostos do mal". Segundo Amós Oz (2017), somente o debate por meio do conhecimento pode evitar que as próximas gerações sejam transformadas em grupos de fanáticos. Esse fanatismo, essa aversão à identidade do outro, se constitui por meio daquilo que se acredita, de forma panfletária, que seja este outro.

\footnotetext{
“”E tudo consequência da globalização!", “A culpa é dos muçulmanos!", “Tudo isso é por causa da permissividade!”, ou "por causa do Ocidente!", ou "por causa do sionismo!", ou "por causa desses imigrantes!", ou "por causa da secularidade!", ou "por causa dos esquerdistas!" - tudo que se tem que fazer segundo essas alegações é apagar o que se acha estar sobrando, marcar com um círculo que lhe pareça o mais correto, depois ir lá e matar esse satã (acompanhado dos seus vizinhos ou de quem por acaso estiver perto), e assim abrir de uma vez todos os portões do paraíso. Cada vez mais, para muita gente, o sentimento público mais forte é o de profunda repulsa. (OZ, 2017, p. 14-15)
}

\section{Os reflexos na sala de aula: uma análise de caso a partir do livro didático}

Este trabalho propõe uma análise de uma coleção de livros didáticos distribuídos pelo Programa Nacional de Livros Didáticos (PNLD) de 2014, com o intuito de observar a forma como o conceito "fundamentalismo" vem sendo abordado no ensino de História da educação básica, bem como a relação estabelecida com a religião muçulmana.

O livro História, Sociedade E Cidadania, escrito por Alfredo Boulos Júnior e publicado pela editora FTD, é apontado pelo PNLD como a coleção de livros mais distribuída no Brasil no último ciclo de distribuição, que foi o do ano de 2015 e vai se estender até 2018, quando deve haver uma nova seleção de obras 
Religare, ISSN: 19826605, v.16, n.1, agosto de 2019, p.35-56.

para serem enviadas às escolas da rede pública nacional. A partir dos dados divulgados pelo MEC, estima-se que cerca de 1.400 .000 livros foram distribuídos em todo o território nacional.

Figura $1^{7}$ - Capa do livro didático de Alfredo Boulos Júnior

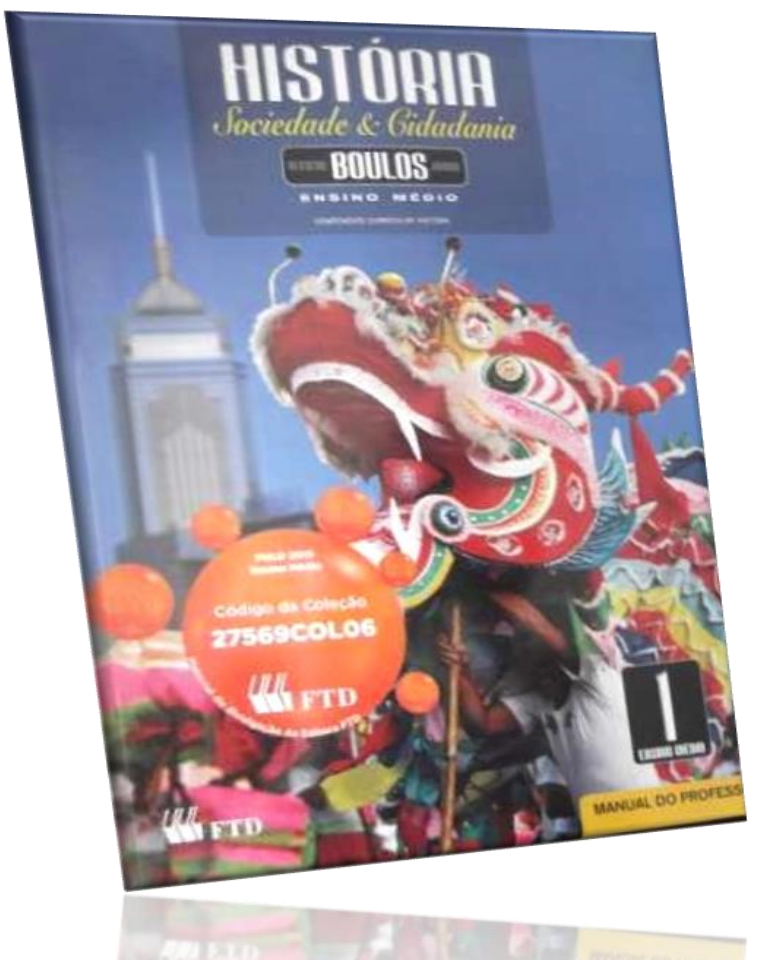

Fonte: BOULOS JUNIOR, Alfredo. História, Sociedade \& Cidadania.

De acordo com o Guia de Livros Didáticos - PNLD 2015, organizado pelo MEC e enviado às escolas para contribuir com a análise e posterior escolha do professor, esta coleção está agrupada em unidades temáticas, que são apresentadas ao leitor através de uma página dupla, com imagens e textos, seguindo de forma linear uma cronologia, abordando temas referentes a chamada História Geral e a História do Brasil.

O parecer ressalta que a coleção trabalha a partir da abordagem política e econômica da História, assim, pode-se perceber que aspectos culturais, como os

TImagem da capa do livro didático BOULOS JUNIOR, Alfredo. História, Sociedade \& Cidadania. $1^{\circ}$ ano. $1^{\underline{a}}$ ed. São Paulo: Editora FTD, 2013. 
Religare, ISSN: 19826605, v.16, n.1, agosto de 2019, p.35-56.

religiosos, aparecem em segundo plano para as narrativas que a coleção constrói. O texto do Guia apresenta uma avaliação positiva da coleção, ressaltando seu compromisso com a formação cidadã dos jovens.

A coleção apresenta compromisso com a promoção de uma formação cidadã ao discutir os temas cidadania, questões ambientais e movimentos sociais em atividades voltadas à reflexão sobre tais questões. Contextualiza a presença da mulher em diferentes momentos da história e utiliza imagens e textos que evidenciam os idosos, as crianças e os adolescentes. (MINISTÉRIO DA EDUCAÇÃO, 2015, p.78)

Pode-se constatar que temas ligados à religiosidade não aparecem como indicativos na análise do MEC, quando este problematiza a formação para a cidadania. Analisando o sumário e a forma como os conteúdos foram divididos tem-se: $1^{\underline{0}}$ ano: 4 unidades divididas em 17 capítulos, $2^{\underline{o}}$ ano: 4 unidades divididas em 16 capítulos e $3^{\circ}$ ano: 4 unidades divididas em 13 capítulos.

O único espaço da coleção que aborda o tema fundamentalismo é o último capítulo do livro do $3^{\text {o }}$ ano do Ensino Médio. Em nenhum outro momento o conceito é abordado. Ele aparece apenas no terceiro volume, ligado a conflitos no Oriente Médio que envolvem populações muçulmanas. Neste volume da coleção "História, Sociedade \& Cidadania" são tratados temas e conteúdos ligados à Segunda revolução industrial, às duas grandes guerras, à Guerra Fria e da história do Brasil a partir da primeira República, indo até uma breve análise do primeiro governo de Dilma Rousseff. Em seu sumário, não fica evidente em que unidade ou capítulo o Oriente Médio ou os muçulmanos serão abordados. (COSTA, 2016)

O último capítulo do livro é "O fim do bloco soviético e a nova ordem mundial" e trata da desagregação da União Soviética nos anos noventa, fazendo reflexões acerca da ascensão da globalização e dos conflitos mundiais a partir desse período. Dentre esses conflitos, estão aqueles que se localizam no Oriente Médio. O material didático apresenta a região como "uma área de 7 milhões e 200 mil quilômetros quadrados, o Oriente Médio encontra-se situado entre três 
Religare, ISSN: 19826605, v.16, n.1, agosto de 2019, p.35-56.

continentes: Europa, Ásia e África e, consequentemente, é atravessado por importantes rotas comerciais que ligam o Extremo Oriente e a Oceania à Europa" (BOULOS, 2013, p. 250).

Dando sequência, o livro trata da formação do Estado de Israel no pósSegunda Guerra Mundial e dos conflitos que seguiram. Esse trecho é acompanhado por um mapa que se intitula "O Oriente Médio dividido pela Liga das nações (1922)". Neste mapa, o Egito não aparece como integrante do Oriente Médio, em contra partida, ao lado do mapa, no texto que segue, há o seguinte relato: “Considerando-se injustiçada pela Liga Árabe, aliança militar formada por Egito, Transjordânia (atual Jordânia), Síria e Líbano, iniciou em 1948 uma guerra contra Israel" (BOULOS, 2013, p. 252).

As informações apresentadas no mapa e na descrição do capítulo podem dificultar a compreensão dos leitores sobre o que seria realmente o Oriente Médio, quais países fariam parte efetivamente e quais povos habitam a região, se são apenas os árabes ou se todos esses povos são seguidores do Islã. No subtítulo "Guerras e mais guerras", o livro estabelece que, após esse período de formação do Estado de Israel, seguiram-se vários conflitos que são descritos pelo material como "guerras entre árabes e judeus", tratando da Guerra de Suez, Guerra dos Seis Dias, a Guerra do Yom Kippur e a Guerra do Líbano.

O livro não apresenta uma descrição a respeito dos conceitos árabe e muçulmano, descrevendo conflitos armados dos quais apareceram países que não foram apresentados como parte do Oriente Médio. Em seguida, o material trata do movimento palestino e apresenta como principais impedimentos para que a paz se estabeleça na região:

a) o fundamentalismo de grupos islâmicos que promovem atentados terroristas contra civis israelenses;

b) o fundamentalismo de lideranças judias que autorizam a construção de assentamentos judeus na parte oriental de Jerusalém, reivindicada pelos palestinos como sua capital;

c) a existência de um muro construído para a proteção dos colonos israelenses na Cisjordânia; 
Religare, ISSN: 19826605, v.16, n.1, agosto de 2019, p.35-56.

d) os interesses das super lucrativas indústrias bélicas que têm se beneficiado com a continuação da Guerra

Tudo isso tem dificultado o caminho para a paz. (BOULOS, 2013, p. 255)

No trecho acima, é possível observar que o fundamentalismo é apresentado em dois tópicos como motivadores dos conflitos na região, contudo não se esclarece o que o conceito significa. Não especifica a diferença entre islâmicos e muçulmanos, além disso, ao colocar os "grupos islâmicos" como promotores de atentados terroristas, enquanto os grupos judeus estariam apenas construindo assentos, o texto pode gerar juízos de valores a respeito de qual grupo é mais ou menos violento.

Após a "Questão Palestina", existem cerca de cinco parágrafos que abordam a revolução ocorrida no Irã, que retirou do poder o ditador Reza Pahlevi, em 1979. O material coloca como um dos principais motivadores para as revoltas ocorridas contra o governo de Pahlevi a tentativa do governante de impor costumes da cultura ocidental sobre a maioria muçulmana do país. Essa maioria, de acordo com o livro didático, depôs o governante e então o líder muçulmano xiita Ruhollah Khomeini, assumiu o poder e proclamou uma República islâmica.

Neste ponto, pode-se perceber o uso equivocado de dois conceitos importantes, "república" e "islâmica", já que não fica claro que tipo de governo foi estabelecido. O Brasil também vive sob um regime de república, então a única diferença entre os dois sistemas políticos seria o fator religioso? Além disso, o conceito de "islâmico" está sendo usado com qual sentido? O que ele representa? Faz referencia à crença religiosa predominante ou a uma forma específica de governo? Além destas questões, quando é feita a referencia aos xiitas, o termo aparece em destaque e, ao lado do texto, em um box informativo ou hipertexto, o conceito aparece destacado e há a seguinte definição para xiita: “Corrente do islamismo que considera o Corão como única fonte de ensinamento religioso. Para os xiitas, somente os parentes do profeta Maomé 
Religare, ISSN: 19826605, v.16, n.1, agosto de 2019, p.35-56.

podem ocupar o mais alto posto político e religioso nos países muçulmanos" (BOULOS, 2013, p. 255).

Palazzo (2014) afirma que uma descrição mais ampla do xiismo em seu surgimento seria a de que esta corrente aceita que existam clérigos e entre eles há um líder (Imã supremo), que seria descendente do profeta. No entanto, as divergências dentro da corrente começam muito cedo, quando da sucessão dos primeiros Imãs. A informação que o livro didático elege como descrição para essa corrente dentro do Islã é deficiente e pode gerar também uma confusão de compreensão, pois ao afirmar que apenas os parentes do profeta Muhammad poderiam assumir o governo em países que aplicam a religião na vida política, ele está afirmando que líderes políticos da atualidade possuem parentesco com o profeta que viveu no século VII.

No mesmo contexto, o livro afirma que o governo de Khomeini uniu política e religião e que "essa unidade entre religião e política com reflexos na área jurídica permite-nos caracterizar o governo de Komeini como expressão do fundamentalismo islâmico" (BOULOS, 2013, p. 255). Novamente, o texto não deixa claro o que é o fundamentalismo e expõe que a união entre a vida legislativa ou jurídica e a religião ou os princípios religiosos ligados ao Islã seria a definição para o fundamentalismo islâmico quando, na verdade, a definição para essa influência religiosa em questões políticas é islamismo e não menciona em nenhum momento que a origem do movimento fundamentalista é cristã e ocidental. (DEMANT, 2014). 
Religare, ISSN: 19826605, v.16, n.1, agosto de 2019, p.35-56.

Figura $2^{8}$ - Detalhe da página 255 do livro didático

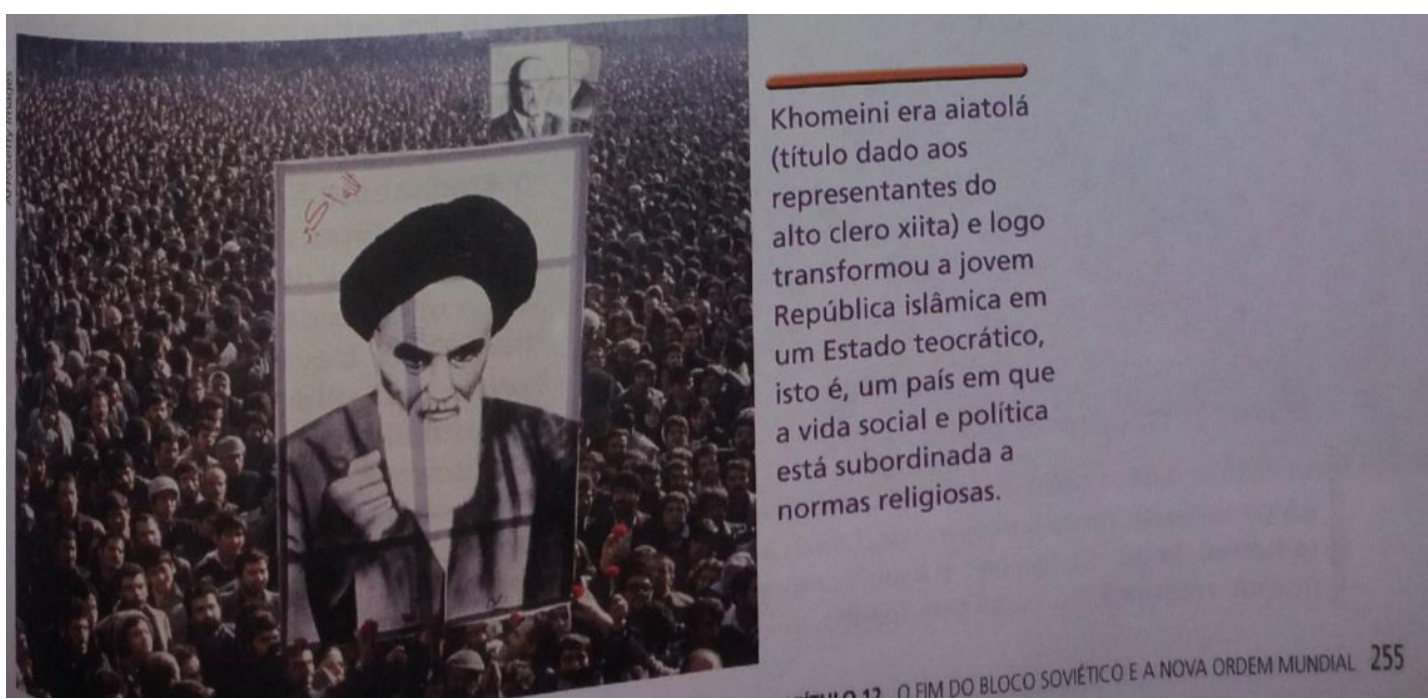

Fonte: AFP/ Getty Imagen

Na sequência, é abordado o caso afegão a partir da tomada de poder do grupo Talebã, nos anos 90, não sendo abordado o contexto histórico de formação do Afeganistão, suas particularidades culturais, as várias etnias formadoras e seus conflitos étnicos ou mesmo a invasão soviética do final dos anos 70. Desta forma, o papel que os Estados Unidos tiveram no fortalecimento de grupos armados, como o próprio Talebã, no contexto da Guerra Fria, ao financiar e equipar grupos locais para irem contra os soviéticos e assim impedir o avanço da influência comunista em um mundo bipolarizado não é problematizado no texto 9 .

Segundo Padovani (2002), os Talebãs são originários do interior do país, das regiões montanhosas que fazem fronteira com o Paquistão. Essas comunidades possuíam práticas culturais muito particulares, a maioria delas era composta por uma população analfabeta e empobrecida. Possuíam costumes e tradições consideradas radicais por muitos afegãos das regiões mais

8Imagem retirada de página do livro didático BOULOS JUNIOR, Alfredo. História, Sociedade \& Cidadania. $3^{\circ}$ ano. $1^{\underline{a}}$ ed. São Paulo: Editora FTD, 2013. Página: 255

9Para mais informações acerca do papel dos Estados Unidos em conflitos periféricos da Guerra Fria, consultar CHOMSKY, Noam. Terrorismo, a arma dos poderosos. Le monde diplomatique, 2001. 
Religare, ISSN: 19826605, v.16, n.1, agosto de 2019, p.35-56.

próximas da capital, Cabul. Mesclavam costumes tribais ou de suas etnias com práticas muçulmanas deturpadas por releituras de seus líderes políticos e religiosos.

Figura $3^{10}$ - Detalhe da página 256 do livro didático

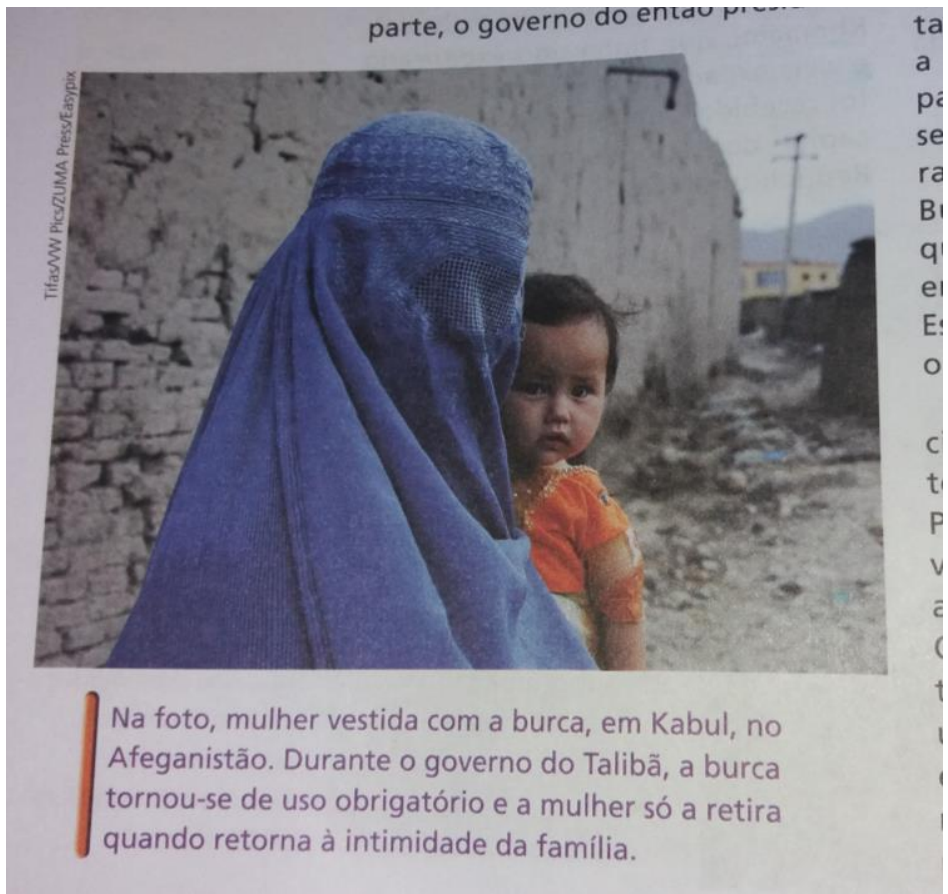

Fonte: Foto: Tifas/VW Pics/ZUMA Press/Easypix

O grupo originário destas localidades se formou como forma de resistência após a invasão soviética, no final dos anos 70, recebendo treinamento e armamentos do Ocidente, entretanto este contexto não é abordado pelo livro didático. Nele consta a informação de que nos anos 90 ocorreu um "renascimento do fundamentalismo islâmico no mundo" (BOULOS, 2013, p. 256). Essa conclusão é equivocada, visto que estudiosos como Padovani (2002) destacam que o fundamentalismo não chegou ao

${ }^{10}$ Imagem retirada de página do livro didático BOULOS JUNIOR, Alfredo. História, Sociedade \& Cidadania. $3^{\circ}$ ano. $1^{\text {a }}$ ed. São Paulo: Editora FTD, 2013. Página: 256 
Religare, ISSN: 19826605, v.16, n.1, agosto de 2019, p.35-56.

Afeganistão com os Talebãs, ele já existia nas áreas do país afastadas da capital, como forma de resistência a influências culturais externas. Sem explicar o conceito apresentado (fundamentalismo islâmico) e nem referenciar quando ele teria começado, já que trata de um novo episódio, o texto didático dá continuidade, afirmando que o Talebã instaurou ditadura teocrática ao tomar o poder.

A partir da análise desta coleção didática, pode-se perceber que o fundamentalismo não é explicado enquanto conceito, nem historicizado em sua origem, sendo relacionado apenas com o Islã, o que pode gerar a percepção equivocada de que este fenômeno está ligado unicamente aos grupos muçulmanos, ignorando sua origem cristã ocidental e a presença de movimentos fundamentalistas em outras religiões, como a judaica e a hindu. A relação entre a dominação Ocidental dos séculos XIX e XX e a disseminação do fundamentalismo muçulmano também não é problematizada.

Isto, aliado às notícias veiculadas por diferentes mídias jornalísticas e de entretenimento que veiculam informações sobre grupos terroristas que se identificam e são identificados como praticantes do Islã, bem como o crescente movimento de xenofobia para com os muçulmanos na Europa e nos Estados Unidos, permeia o cotidiano dos alunos da educação básica que trazem essas percepções para a sala de aula. Percepções estas que se não são reforçadas, também não são problematizadas e criticadas pelos textos didáticos.

Por vezes o professor encontra-se em meio a esse conjunto de discursos, percepções e informações, muitas vezes rasas e deturpadas, de modo que se torna importante estimular este docente a estar preparado teórico e didaticamente para problematizar tais questões contemporâneas que envolvem as comunidades muçulmanas, especialmente quando estas são descritas de maneira insuficiente nos materiais didáticos.

\section{Considerações finais}


Religare, ISSN: 19826605, v.16, n.1, agosto de 2019, p.35-56.

Este trabalho não teve o objetivo de realizar um estudo amplo sobre a forma como o fundamentalismo e o fundamentalismo muçulmano são abordados nas coleções de livros didáticos de História no Brasil, mas propor uma análise de caso sobre o contexto e a forma pela qual o fundamentalismo religioso é abordado no Ensino de História. Para isso, utilizou-se como fonte a coleção de livros didáticos "História, Sociedade \& Cidadania" que foi a coleção mais distribuída para as escolas públicas brasileiras através do PNLD de 2014.

Nesta coleção, observou-se que a origem do fundamentalismo religioso não é trabalhada e que o espaço destinado ao tema na coleção didática é restrito, sendo encaixado no terceiro volume da coleção, relacionado aos conflitos "do mundo globalizado". Estes conflitos focam no Oriente Médio e colocam como plano de fundo questões religiosas. Desta forma, é possível observar que o material didático aponta o fundamentalismo muçulmano como uma das causas dos conflitos.

É importante ressaltar que o fundamentalismo muçulmano contribuiu para a formação de grupos violentos que realizaram ações terroristas de intolerância tanto religiosa, quanto política, contudo, o fundamentalismo religioso não se reduz a grupos violentos, nem à religião muçulmana. Ele nasce através de um movimento cristão moderno nos Estados Unidos, como uma resposta a mudanças sociais, políticas e culturais que ocorreram no início do século XX, isto é, origina-se como uma tentativa de "purificar" ou "preservar" as práticas religiosas consideradas "puras", "essenciais" ou "fundamentais", em uma ânsia de manter certa ordem social através do culto e dos rituais religiosos.

Contudo, esta percepção da construção histórica do fundamentalismo dentro de diferentes religiões se perde no atual contexto, onde, devido em parte ao discurso midiático e a ações de grupos fundamentalistas muçulmanos violentos que usam os modernos meios de comunicação para divulgar suas ações e sua ideologia, acaba-se por homogeneizar o fenômeno do 
Religare, ISSN: 19826605, v.16, n.1, agosto de 2019, p.35-56.

fundamentalismo, além de estabelecer uma relação direta com o Islã. Ignoramse suas raízes cristãs ou mesmo a presença de grupos fundamentalistas em outras vertentes religiosas.

Por fim, percebe-se que o tema no ensino de História carece de profundidade e material para o desenvolvimento do estudo. No atual contexto, no qual notícias que relatam ações extremadas circulam pelos meios de comunicação, ataques a civis, intolerância e ódios que usam como plano de fundo contextos religiosos, é importante que o ensino de História problematize essas questões.

Também se observa a necessidade dos estudos sobre religiosidades ganharem mais espaço nas salas de aula, sobretudo no ensino de História. O século XXI vem proporcionando um protagonismo das questões religiosas nas questões sociais. A História precisa se apropriar deste debate para construir saberes escolares que permitam ao estudante compreender o debate sobre o tema. Como compreender as diferentes manifestações fundamentalistas sem entender as correntes religiosas? Como questionar o radicalismo islâmico sem conhecer o Islã?

Quando se verificam ou listam esses fatos, só se pode chegar à conclusão de que a religião retornou à história. Não conseguimos mais entender a situação do mundo atual se não tivermos dispostos a reconhecer que a religião também é um fator do processo histórico. Para quem foi formado na tradição iluminista ocidental, [...], essa constatação é sinistra. Sinistra porque o surgimento de movimentos fundamentalistas evidencia que a História da Modernidade segue um curso diferente daquele propalado pelo culto à razão. [...] No entanto, o retorno da religião não é apenas fundamentalismo. É necessário que se pergunte pela importância cultural desses movimentos religiosos. Eles são expressão autêntica da cultura de nossos dias. (DREHER, 2006, p. 88-89)

O estudo das religiões e religiosidades, em uma perspectiva não confessional e direcionada ao entendimento das questões sociais e históricas, 
Religare, ISSN: 19826605, v.16, n.1, agosto de 2019, p.35-56.

deve fornecer ao estudante instrumental conceitual que o permita diferenciar as práticas religiosas em suas versões fundamentalistas, extremistas e fanáticas, contribuindo para um debate social que seja capaz de desconstruir a "guerra de civilizações, travada sobretudo entre o Islã e a cultura ocidental" (OZ, 2017, p. 12).

O conhecimento deve permitir que o aluno desconstrua a crença da superioridade cultural do ocidente laico e da inferioridade do oriente religioso e arcaico. Somente por meio do entendimento da importância histórica e cultural do Islã, o estudante será capaz de separar atos de violência das práticas religiosas, sendo tolerante com todas as manifestações de fé. Além disso, também será capaz de observar que atos violentos acontecem em todas as crenças e culturas. O saber escolar precisa desmistificar o Islã.

Muitos esquecem que o Islã radical não detém nenhum monopólio sobre o fanatismo violento. [...] O fanatismo é mais antigo que o Islã. Mais antigo do que o cristianismo e o judaísmo. Mais antigo do que toda a ideologia que existe no mundo. [...] Genocídio e jihad e cruzadas, Inquisição e gulags e campos de extermínio e câmaras de gás, porões de tortura a atentados terroristas indiscriminados, nada disso é novidade, e quase todos esses tipos de manifestações antecederam em muitos séculos a ascensão do Islã radical. (OZ, 2017, p. 13-14)

O ensino de História no Brasil tem sido alvo de debates em várias esferas, onde se discute desde o sentido de estudar o assunto até as novas abordagens possíveis para o trabalho em sala de aula. Na academia, percebe-se um movimento de reflexão da prática pedagógica de professores historiadores, contudo a transposição destas discussões para a realidade da escola básica tem acontecido de forma lenta e pausada.

De acordo com Monteiro (2009), é dado papel de destaque ao livro didático na organização curricular escolar e, por vezes, no planejamento das aulas do professor, de modo que ele se torna central no processo de ensino aprendizagem, substituindo, muitas vezes, alunos e professores enquanto 
Religare, ISSN: 19826605, v.16, n.1, agosto de 2019, p.35-56.

sujeitos da construção do saber. A indústria editorial recebe grandes quantias em dinheiro, graças a políticas públicas, e sofre avaliações de conteúdo por parte do Ministério da Educação (MEC), porém essa indústria ainda estabelece um discurso que condiz com a cultura dominante, propagando ideologias que necessitam de problematizações, situação na qual a figura do professor não pode ser substituída.

Este trabalho não tem o objetivo de esgotar as possibilidades de pesquisa sobre o tema ou sobre a análise de coleções didáticas, mas sim oferecer um estudo acerca das particularidades do fundamentalismo muçulmano e da sua abordagem no ensino de História através da análise de uma coleção de livros didáticos.

Estimular o senso crítico dos alunos, o respeito às diferenças, a tolerância e a prática da cidadania são funções do ensino de História. Desta forma, é importante problematizar o fundamentalismo religioso na sala de aula como estratégia para criar condições que levem a construção de uma formação mais plural dos alunos e sirva de estímulo para o fim da intolerância religiosa. Sem estas percepções, preconceitos podem ser enraizados e estereótipos propagados. A educação e o ensino de História possuem papel fundamental na formação de cidadãos menos preconceituosos, mais críticos e participativos na sociedade, já que têm a função de desenraizar preconceitos, problematizar estereótipos e questionar ideologias que levam a construção da intolerância religiosa.

\section{Referências}

ARMSTRONG, Karen. Em nome de Deus: O Fundamentalismo no judaísmo, no cristianismo e no islamismo. Trad. Hildegard Feist. São Paulo: Companhia das Letras, 2009.

BOULOS JÚNIOR, Alfredo. História, Sociedade e Cidadania, vol. 1, 2 e 3. São Paulo: FTD, 2013.

CHOMSKY, Noam. Verdades e mitos sobre a Invasão do Iraque. Socialist Register, 2004. p. $161-174$ 
Religare, ISSN: 19826605, v.16, n.1, agosto de 2019, p.35-56.

Terrorismo, a arma dos poderosos. Trad. Iraci Poleti. Publicado originalmente In: Le monde diplomatique, 2001.

COSTA, Jéssica Pereira da. O estuda da História do Islã e dos muçulmanos na educação básica: Conceitos e Representações. Dissertação (Mestrado) - Universidade de Caxias do Sul, Programa de Pós-graduação em História. Caxias do Sul, p.107. 2016.

DEMANT, Peter. O Mundo Muçulmano. São Paulo: Contexto, 2004.

DREHER, Martin Noerberto. Fundamentalismo. São Leopoldo: Sinodal, 2006.

HOURANI, Albert. Uma história dos povos árabes. São Paulo: Cia. das Letras, 1994.

LIA, Cristine Fortes. História das religiões e religiosidades: contribuições e novas abordagens. Aedos: Revista do Corpo Discente do Programa de PósGraduação em História da UFRGS (Online), v. 4, p. 549-563, 2012. Disponível em: < http://seer.ufrgs.br/aedos/article/view/31208> Acesso em: junho de 2015

LIA, Cristine Fortes; RADÜNZ, Roberto. Os monoteístas no mundo contemporâneo: judeus, cristãos e muçulmanos. Revista Brasileira de História das Religiões. ANPUH, Maringá (PR) v. V, n.15, jan/2013. ISSN 1983-2850 Dossiê Memória e Narrativas nas Religiões e nas Religiosidades. Disponível em: http://www.dhi.uem.br/gtreligiao/pub.html

LEENHARD Jacques. Caminhos teóricos para o estudo das religiões. Revista Brasileira de História das Religiões. ANPUH, Ano V, n. 14, Setembro 2012. Disponível em: < http://www.dhi.uem.br/gtreligiao /index.html>. Acesso em out. 2015.

MATOS, Júlia Silveira. Ensino de História, Diversidade e os livros didáticos: história, políticas e mercado editorial. Rio Grande: Ed. Da Universidade Federal de Rio Grande, 2013.

MINISTÉRIO DA EDUCAÇÃO, Histórico do Programa Nacional do Livro Didático (PNLD) Disponível em: <http://www.fnde.gov.br/programas/livrodidatico/livro-didatico-historico $>$. Acesso em 19 de janeiro de 2016.

MINISTÉRIO DA EDUCAÇÃO, Guia de livros didático PNLD 2015: Ensino Médio. História. Brasília, Ministério da Educação, Secretaria de Educação Básica, 2014.

MONTEIRO, Ana Maria F.C. Professores e livros didáticos: narrativas e leituras no ensino de história. IN: MAGALHÃES, M. de S.; REZNIK,L.; ROCHA, H. (Orgs.) A História na escola: autores, livros e leituras. Rio de Janeiro: FGV 
Religare, ISSN: 19826605, v.16, n.1, agosto de 2019, p.35-56.

Editora/FAPERJ, 2009.

MONTENEGRO, Sílvia M. Discursos e contra discursos: o olhar da mídia sobre o islã no Brasil. Mana. Rio de Janeiro: UFRJ. n.1, vol. 8, Abr. 2008.

OZ, Amós. Mais de uma luz: fanatismo, fé e convivência no século XXI. São Paulo: Companhia das Letras, 2017.

PALAZZO, Carmen Lícia. As Múltiplas faces do Islã. Seculum - Revista de História. n. 30, João Pessoa, jan-jun 2014. p.161-176

PINSKY, Jaime (Org.) O ensino de História e a criação do fato. São Paulo: Contexto, 2012.

PROTO, Leonardo Venicius Parreira. História dos conceitos: fundamento teórico-metodológico para a construção da historiografia. Revista Espaço Acadêmico. no 122 , julho de 2011.

SAID, Edward W. Orientalismo: o Oriente como invenção do Ocidente. São Paulo: Companhia das Letras, 2007.

SARDAR, Ziauddin. Em que acreditam os muçulmanos? Rio de Janeiro: Civilização Brasileira, 2010.

SOUZA, Felipe Freitas de. Apontamentos sobre o Islã no Brasil: Islamofobia e notas sobre o xiismo brasileiro. Revista Diversidade Religiosa, João Pessoa, v. 6, n. 2, 2016. p. 152-178.

TODOROV, Tzvetan. O medo dos bárbaros: para além do choque de civilizações. Rio de Janeiro: Vozes, 2010.

Recebido em 14 - 09- 2018

Aprovado em 21 - 07 - 2019 